\title{
A unique, large-sized stem Odonata (Insecta) found in the early Pennsylvanian of New Brunswick (Canada)
}

\author{
Olivier Béthoux ${ }^{1}$, Rowan E. Norrad ${ }^{2}$, Matthew R. Stimson ${ }^{3,4}$, Olivia A. King ${ }^{3,4}$, Luke F. Allen ${ }^{2}$, \\ Isabelle Deregnaucourt ${ }^{1}$, Steven J. Hinds ${ }^{5}$, Jake H. Lewis ${ }^{3,6}$, and Jörg W. Schneider ${ }^{7,8}$ \\ ${ }^{1}$ CR2P (Centre de Recherche en Paléontologie - Paris), MNHN - CNRS - Sorbonne Université, 57 rue Cuvier, CP38, \\ 75005, Paris, France \\ ${ }^{2}$ Citadel High School, 1855 Trollope St., Halifax, Nova Scotia, B3H 0A4, Canada \\ ${ }^{3}$ Steinhammer Paleontological Laboratories, Geology/Paleontology section, Natural History Department, \\ New Brunswick Museum, 277 Douglas Ave, Saint John New Brunswick, E2K 1E5, Canada \\ ${ }^{4}$ Department of Geology, Saint Mary's University, 923 Robie St., Halifax, Nova Scotia, B3H 3C3, Canada \\ ${ }^{5}$ Geological Surveys Branch - New Brunswick Department of Natural Resources and Energy Development, \\ 135 Regent St., Fredericton, New Brunswick, E3C 2G6, Canada \\ ${ }^{6}$ Canadian Museum of Nature, 1740 Pink Road, Gatineau, Quebec, J9J 3N7, Canada \\ ${ }^{7}$ TU Bergakademie Freiberg, Institut für Geologie, Bernhard-von-Cotta-Straße 2, 09596, Freiberg, Germany \\ ${ }^{8}$ Kazan Federal University, Institute of Geology and Petroleum Technologies, Kremlyovskaya 18, 420008, Kazan, Russia
}

Correspondence: Olivier Béthoux (obethoux @mnhn.fr)

Received: 19 February 2021 - Revised: 21 May 2021 - Accepted: 25 May 2021 - Published: 2 July 2021

\begin{abstract}
A stem relative of dragon- and damselflies, Brunellopteron norradi Béthoux, Deregnaucourt and Norrad gen. et sp. nov., is documented based on a specimen found at Robertson Point (Grand Lake, New Brunswick, Canada; Sunbury Creek Formation; early Moscovian, Pennsylvanian) and preserving the basal half of a hindwing. A comparative analysis of the evolution of wing venation in early odonates demonstrates that it belongs to a still poorly documented subset of species. Specifically, it displays a $\mathrm{MP}+\mathrm{CuA}$ fusion, $\mathrm{a} \mathrm{CuA}+\mathrm{CuP}$ fusion, and a $\mathrm{CuP}+\mathrm{AA}$ fusion, but it lacks the "extended" $\mathrm{MP}+\mathrm{Cu} / \mathrm{CuA}$ fusion and the "extended" $(\mathrm{CuP} / \mathrm{CuA}+\mathrm{CuP})+\mathrm{AA}$ fusion, the occurrence of which is typical of most Odonata, including Meganeura-like species. The occurrence of intercalary veins suggests that its closest relative might be Gallotypus oudardi Nel, Garrouste and Roques, 2008, from the Moscovian of northern France.
\end{abstract}

\section{Introduction}

Conjecture of primary homology in wing venation of extant dragon- and damselflies (Odonata) remained a matter of debate for most of the 20th century. Despite the ancient Meganeura-like insects being known, attempts to relate the wing venation of stem and crown Odonata to other insect groups abutted a number of issues. Among them was the propensity, in odonate wings, of cross-veins to convert into main-vein-like elements, including so-called "intercalary veins", which can prove difficult to distinguish from surrounding genuine main veins. Confusion also arose from persisting gaps in the documentation of venation patterns which had experienced intense modifications since the Pennsylvanian.

A landmark in this debate was the proposal made by Tillyard (1925b), who, at that time, had adopted the view that the insect wing venation ground plan is composed of a number of primary veins sharing the same branching pattern, specifically a convex, anterior branch and a concave, posterior one, also known as the serial ground plan (Lameere, 1922, 1923; contrast with Tillyard, 1925a, in which the author expressed doubts on the adequacy of the Comstock-Needham terminol- 
ogy, he used previously). It is relevant to first emphasize that even though Tillyard (1925b, p. 42) stressed that Protodonata (including, in his opinion, Meganeuridae and a few other species) and Odonata were two clearly distinct taxa, he also stated that MP and $\mathrm{CuA}\left(\right.$ his $\mathrm{Cu}_{1}$ ) were not only present as free veins beyond the wing base in Meganeuridae but also in species he regarded as stem Zygoptera, i.e. crown Odonata. It follows that Tillyard, in some respect, regarded a subset of Protodonata as stem Odonata (and see Tillyard and Fraser, 1938).

The key point in Tillyard's thesis from 1925 (Tillyard, 1925b) is the presumed loss of MP and CuA as free veins, beyond the wing base. He derived this view from the study of a remarkable specimen of a Meganeura-like species composed of a negative imprint of a hindwing recovered from Elmo (Kansas, USA; Wellington Formation; Artinskian, early Permian; Fig. 1a, b, d, e). Unlike previously known species, vein elevations were preserved in a pristine manner in this material. Tillyard recognized a fusion of $\mathrm{M}$ with $\mathrm{R}$, owing to the occurrence, after $\mathrm{ScP}$, of two closely adjoined veins. The resulting vein further splitting into a convex vein (certainly RA), a concave vein (certainly RP) and a convex vein (likely MA), the concave MP had to have vanished. He observed what he believed was a remnant of it (besides R and MA?), basal to the split of RA and RP + MA (red-filled broad arrow on Fig. 1d), but we could not corroborate his observation (only two veins occur). Tillyard also noted a loop, near the wing base, he regarded as formed by $\mathrm{CuA}$ and $\mathrm{CuP}$ diverging and fusing shortly afterwards. The resulting vein being concave, and therefore presumably composed of $\mathrm{CuP}$, the convex $\mathrm{CuA}$ had to have vanished. Finally, a strong oblique structure, his "anal crossing", located between $\mathrm{CuP}$ (his $\mathrm{Cu}_{2}$ ) and AA (his 1A), was not regarded as part of the main veins scheme, despite its strength. This proposal was further formalized in Tillyard and Fraser (1938) and was followed for decades, including prominent textbooks (e.g., Carpenter, 1992; Rohdendorf, 1962).

This paradigm was challenged by Riek and KukalováPeck (1984; and see Riek, 1976), who described two critical, early Pennsylvanian species, Eugeropteron lunatum Riek in Riek and Kukalová-Peck, 1984 and Geropteron arcuatum Riek in Riek and Kukalová-Peck, 1984, displaying (i) at the wing base, a set four well-delimited veins between $\mathrm{ScP}$ and AA (there are three in Meganeura-like species, two in extant Odonata), interpreted as RA, RP, M and $\mathrm{Cu}$, successively, and (ii) in the distal area, a complete set of MA, MP, $\mathrm{CuA}$, $\mathrm{CuP}$ and AA veins. These insects could be related to Odonata owing to a sequence of vein fusions where they compose the earliest configurations. Under this scheme, a MP $+\mathrm{CuA}$ fusion was acquired in early stem Odonata, then further extended into a $\mathrm{MP}+\mathrm{Cu} / \mathrm{CuA}$ fusion. This made Tillyard's $\mathrm{CuP}$ and $\mathrm{AA}$ available for being interpreted as the supposedly missing MP and $\mathrm{CuA}$, respectively, and his "anal crossing" interpretable as secondarily fused $\mathrm{CuA}$ and $\mathrm{CuP}$, an unusual configuration among Meganeura-like species (this stem then fuses with AA; Fig. 1c, f). This evolutionary scheme definitely reconciled the wing venation of Odonata with the serial insect wing venation ground plan: at the wing base, all extant Odonata possess a $\mathrm{R}+\mathrm{MA}$ stem and a $\mathrm{MP}+\mathrm{Cu}$ (or $\mathrm{MP}+\mathrm{Cu}+\mathrm{AA}$ ) stem. This proposal was applied at the scale of the entire order by Bechly (1996), who also provided an extensive systematic framework derived from the new conjectures of primary homology. These conjectures were corroborated by detailed analysis of wing base structures in extant Odonata (Jacquelin et al., 2018) and are widely accepted nowadays. A recent proposal made by Trueman and Rowe (2019a; and see associated debate; Nel et al., 2019; Trueman and Rowe, 2019b) lacks relevance as a consequence of ignoring Eugeropteron-like species, arguably the most important ones to address the question of wing venation homologies in Odonata.

Aspects of comparatively minor importance remained unclear, notably the actual course of $\mathrm{M}$ and $\mathrm{MA}$ in Eugeropteron-like species. Béthoux (2015) proposed an alternative to Riek and Kukalová-Peck's interpretation of the four veins located between $\mathrm{ScP}$ and $\mathrm{AA}$ at the wing base in these odonates, as follows: RA (as opposed to R), MA (as opposed to RP), MP (as opposed to M), and $\mathrm{Cu}$ (unchanged). In other words, instead of assuming an $\mathrm{R}$ system splitting into RA and RP at the very wing base, as proposed by Riek and Kukalová-Peck, Béthoux assumed that the M system, instead, is split at the very wing base. This is more consistent with the prediction by Riek and Kukalová-Peck that, in extant Odonata, $\mathrm{MA}$ is fused with $\mathrm{R}$, and $\mathrm{MP}$ with $\mathrm{Cu}$, from the wing base (which implies a very early split of the $\mathrm{M}$ system indeed). Another alternative was proposed by Petrulevičius and Gutiérrez (2016), with RA, RP + MA, MP, and Cu composing the four veins of interest, but this implies that both $\mathrm{R}$ and $\mathrm{M}$ systems are split at the wing base and is therefore a less parsimonious conjecture.

Despite the abundance of Late Palaeozoic strata in Atlantic Canada (Gibling et al., 2019), evidence of fossil insects is rare, with examples preserved in the Pennsylvanian strata at the UNESCO World Heritage site at Joggins, Nova Scotia (Calder et al., 2006; Prokop et al., 2017; Faulkner et al., 2017); Sydney Mines, Nova Scotia (Dawson, 1878; Copeland, 1957); and Fern Ledges, New Brunswick (Matthew, 1909). A single unpublished specimen has been collected from the early Permian strata of Brule, Nova Scotia (Van Allen et al., 2005). Herein we report the discovery of a hindwing from the Sunbury Formation (New Brunswick) displaying a wing venation pattern known to occur in a subset of yet poorly documented stem Odonata. Owing to its combination of character states and its large size, it composes a remarkable addition to the group. 
(a)

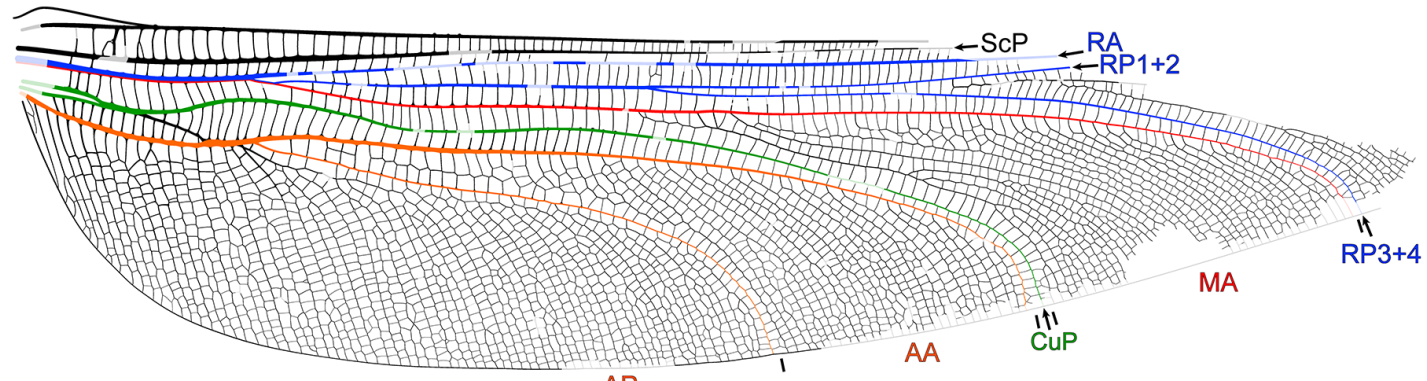

$\mathrm{AP}$

(b)

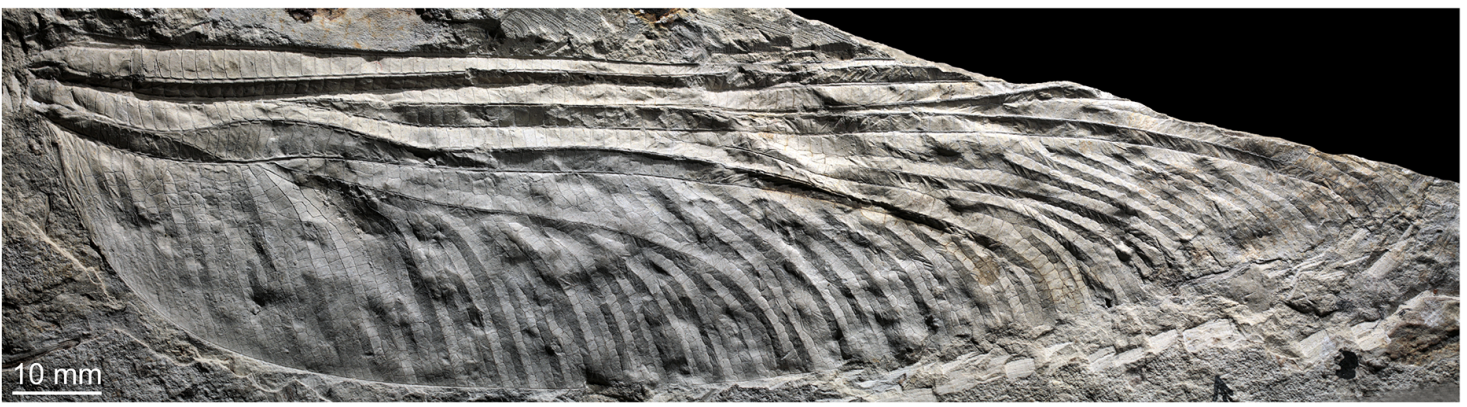

(c)
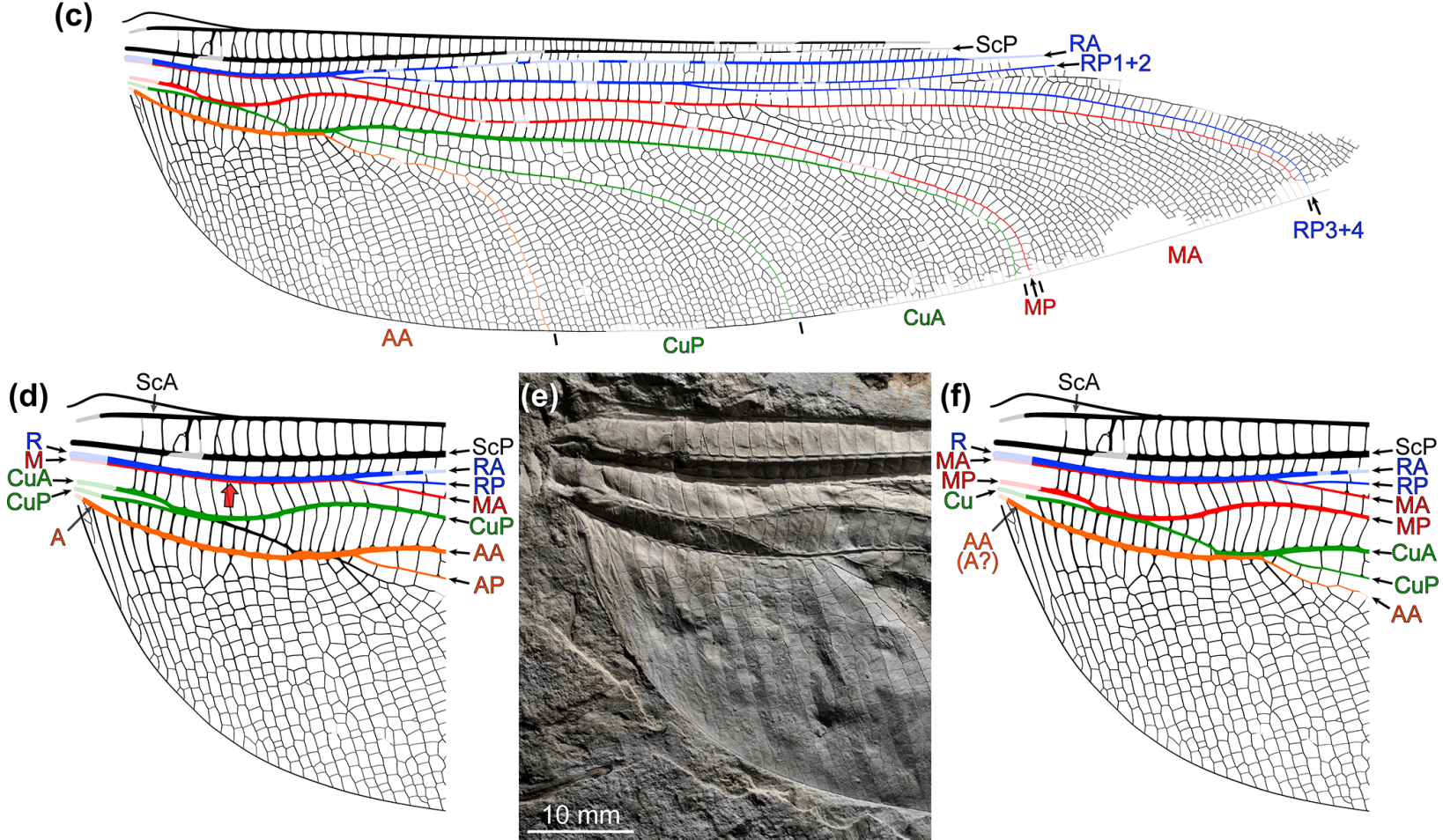

Figure 1. Megatypus schucherti Tillyard, 1925, holotype (specimen YPM IP 001021a): (a-c) overview and (d-f) detail of wing base; (a, d) interpretative drawing, conjectures of primary homology according to Tillyard (1925b) (in d, broad red arrow indicates the location of the distinct MP allegedly observed by Tillyard); (b, e) photograph (dry, flipped horizontally); (c, f) interpretative drawing, conjectures of primary homology according to Riek and Kukalová-Peck (1984).

\section{Material and methods}

The specimen NBMG 21589, which is the focus of this contribution, is deposited at the New Brunswick Museum (palaeontology collection; Saint John, New Brunswick, Canada). The specimen YPM IP 001021a, also illustrated, is housed at the Yale Peabody Museum (New Haven, MA, USA). Specimen numbers associated with the abbreviations MB and WMNM are housed at the Museum für Naturkunde Berlin (Berlin, Germany) and the Westfälisches Museum für Naturkunde Münster (Münster, Germany), respectively. 
Photographs of fossil material reproduced in this account were taken using a digital camera Canon EOS 5D Mark III (Canon, Tokyo, Japan) coupled to a Canon $50 \mathrm{~mm}$ macro lens (equipped with polarizing filter). The resulting photographs were optimized using Adobe Photoshop CS6 (Adobe Systems, San Jose, CA, USA). The photograph reproduced in Fig. 1 was generated by manually stitching five individual photographs of different areas of the specimen in dry conditions. The photograph reproduced in Fig. $6 \mathrm{~b}$ is a combination of photographs of the specimen dry and immersed in ethanol (composite photograph).

Two reflectance transformation imaging (RTI) files were generated to further document the specimen NBMG 21589 (for details of this technique as applied to fossil insect imprints see Béthoux et al., 2016). For each file, 42 photographs were taken using a ca. $30 \mathrm{~cm}$ diameter automated light dome driving a digital camera Canon EOS 5D Mark III coupled to a Canon MP-E $65 \mathrm{~mm}$ macro lens. Original photographs were optimized using Adobe Photoshop CS6 before RTIprocessing, itself achieved using the RTIbuilder software (Cultural Heritage Imaging). We provide an online Dryad dataset (Béthoux et al., 2021) containing these two RTI files. Items composing Fig. 7 were extracted from them using the normals visualisation mode, which assigns a colour code to each pixel according to the orientation of the vector perpendicular to the tangent plane of the object at the corresponding point. These extracts were optimized for contrast.

Hand-drawn sketches were prepared for both YPM IP 001021a and NBMG 21589 specimens with the aid of a Zeiss SteREO Discovery V8 stereomicroscope, equipped with a pair of W-PL $10 \times / 23$ eye pieces, a Plan Apo S $1.0 \times$ objective, and a drawing tube (all Jena, Germany). Then final vector drawings were prepared using Adobe Illustrator CS6 (Adobe Systems) using the scanned hand-drawn sketches and photographs, as well as RTI extracts for the specimen NBMG 21589. The final drawing of the specimen YPM IP 001021a involved manual adjustments to correct for areas that are creased on the specimen.

We use wing venation homology conjectures proposed by Riek and Kukalová-Peck (1984) and Béthoux (2015) for Odonata. Corresponding abbreviations are as follows: ScP, posterior subcosta; $\mathrm{R}$, radius; $\mathrm{RA}$, anterior radius; $\mathrm{RP}$, posterior radius; $\mathrm{M}$, media; MA, anterior media; $\mathrm{MP}$, posterior media; $\mathrm{Cu}$, cubitus; $\mathrm{CuA}$, anterior cubitus; $\mathrm{CuP}$, posterior cubitus; AA, anterior analis. Colour-coding is as follows: blue, radial system; red, median system; green, cubital system (dark green, $\mathrm{CuA}$; light green, $\mathrm{CuP}$ ); orange, anal system; purple, concave intercalary vein; yellow, convex intercalary vein.

Before proceeding, it is necessary to define the term "fusion", as applying to wing veins, as unambiguously as possible. First, "vein fusion" can be understood veins being simply adjoined for some distance or veins sharing their lumen; and, in the latter case, keeping their respective tracheae distinct or fused into a single one. Only the first condition can

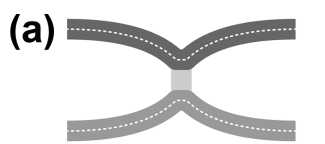

(b)
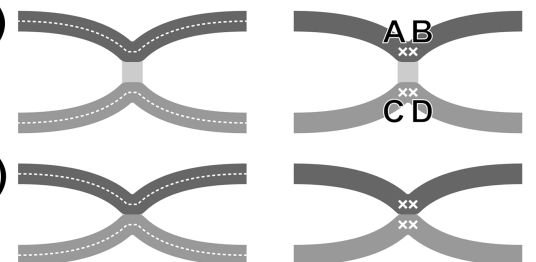

(c)

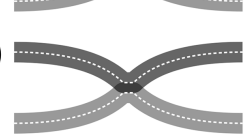

(d)
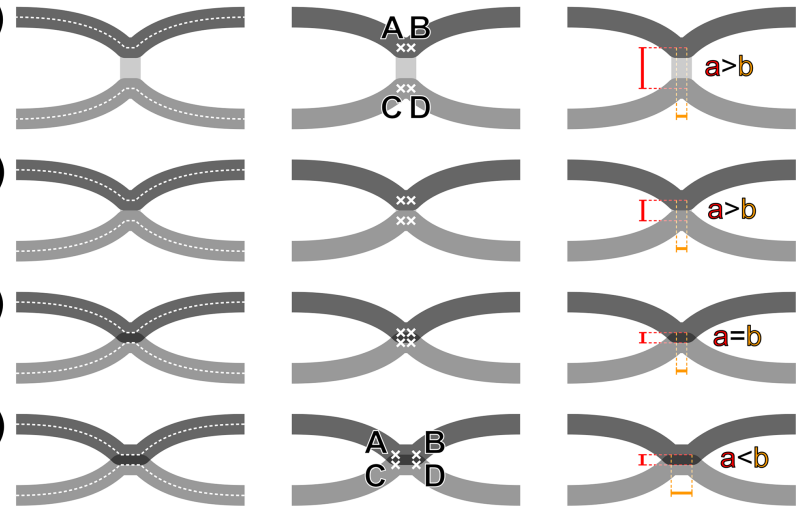

Figure 2. Characterization of vein fusion: (a) two veins are connected by a cross-vein, the points $\mathrm{A}$ and $\mathrm{B}$ overlap, and $\mathrm{C}$ and D overlap, distance $a$ is superior to distance $b$; (b) two veins are briefly connected, the points A and B overlap, and C and D overlap, distance $a$ is slightly superior to distance $b$; (c) two veins are connected, the points A, B, C and D overlap, distance $a$ equates distance $b$; (d) two veins are fused, the points $\mathrm{A}$ and $\mathrm{C}$ overlap, and $\mathrm{B}$ and $\mathrm{D}$ overlap, distance $a$ is inferior to distance $b$.

be clearly inferred in the rock imprint record of insects, and it is the focus of the following. The states where two veins are connected by a cross-vein (Fig. 2a), briefly connected (Fig. 2b), connected (Fig. 2c), or fused (Fig. 2d) can be described by objective values derived from four points (A-D), placed along the median axes of each main vein, as follows: $\mathrm{A}$ and $\mathrm{B}$ are located along the anterior vein, and $\mathrm{C}$ and $\mathrm{D}$ along the posterior one; $\mathrm{A}$ and $\mathrm{C}$ are located at the first point of inflexion of each vein, and $\mathrm{B}$ and $\mathrm{D}$ at the second point of inflexion of the each vein. The AC (and BD) distance is $a$, while the $\mathrm{AB}$ (and $\mathrm{CD}$ ) distance is $b$. In practice, the distance $b$ is negligible or null in cases represented in Fig. 2a-c. However, it sometimes occurs that a vein forms a brief plateau when connected to a particularly thick cross-vein, in which case two inflexion points occur indeed, at the beginning and end of the plateau. Similarly, the distance $a$ is negligible or null in cases represented in Fig. 2c-d. It has a value when the two veins do not fully overlap (i.e. when the fused section is thicker than the individual veins). Fusion is qualified when $a<b$ (Fig. 2d).

\section{Geological context}

In New Brunswick, the Devonian-Carboniferous strata were deposited within a triangular region that covers roughly $25900 \mathrm{~km}^{2}$ within the approximate $250000 \mathrm{~km}^{2}$ area of the Maritimes Basin (Williams, 1974; Ball et al., 1981; Lavoie et al., 2009; St. Peter and Johnson, 2009; Dietrich et al., 2011; Gibling et al., 2019). Seven geological groups are preserved within the New Brunswick portion of the Maritimes Basin (Gibling et al., 2019), the youngest of these being the Pictou Group. Within this group, the 

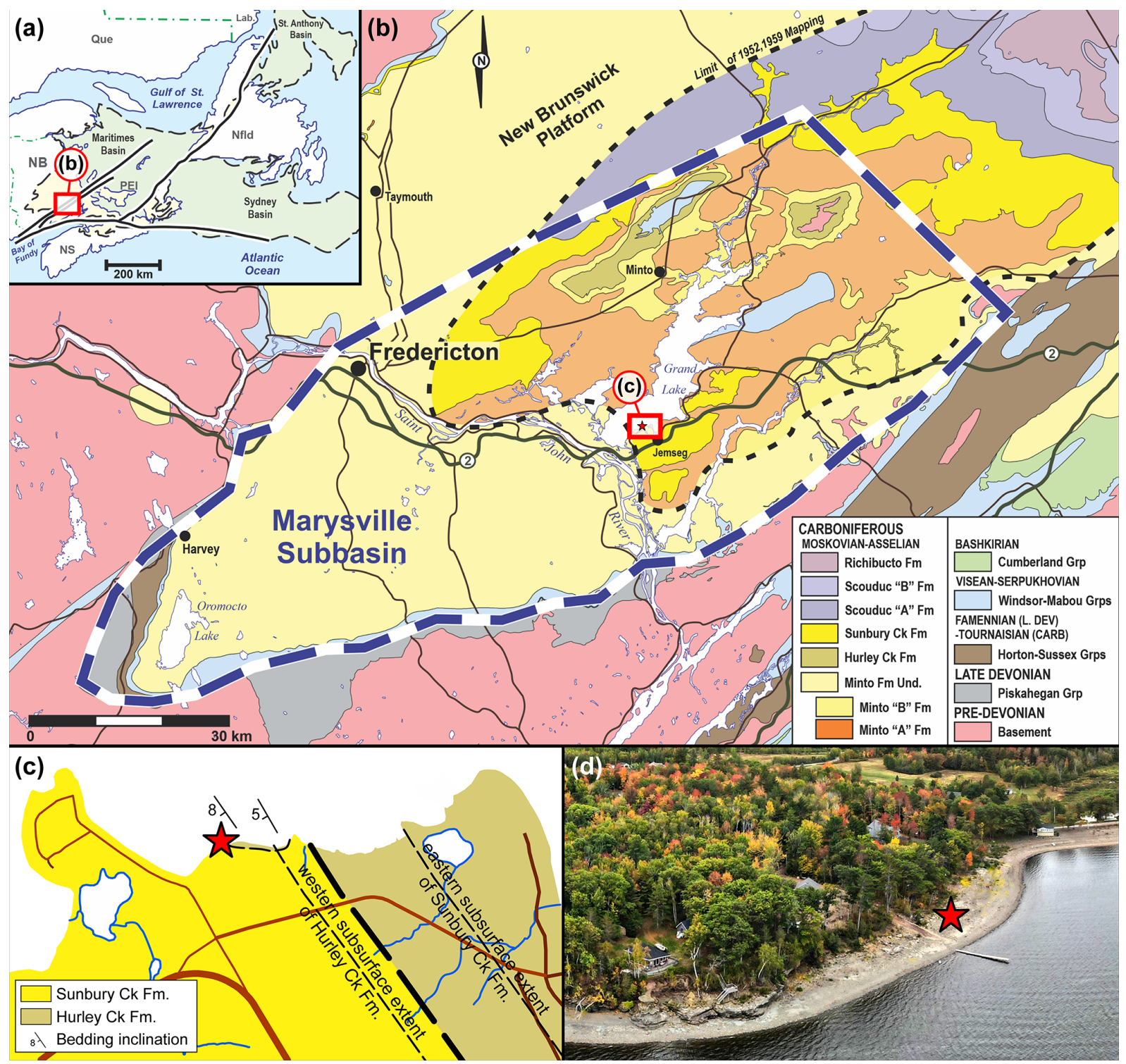

Figure 3. Geological context (red stars indicate the location of the finding of Brunellopteron norradi Béthoux, Allen, Norrad and Deregnaucourt gen. et sp. nov.): (a) map of the Atlantic Canadian provinces indicating the geographic extend of the latest Devonian to earliest Permian Maritimes Basin (after St. Peter and Johnson, 2009 and Gibling et al., 2019); (b) geological map of a portion of the Maritimes Basin known as the Marysville Subbasin, location as indicated in (a) (after Dyer, 1926; Muller, 1951; Hamilton, 1960, 1962a, b, c; and van de Poll et al., 1995); (c) geological map of Robertson Point, location as indicated in (b); (d) aerial photograph of the fossil site (photograph courtesy of Martin Montplaisir, Gregory MacInnis and Jason Raworth).

oldest strata have been assigned to formations as early as the Bashkirian-Moscovian boundary, which sits conformably above the underlying Bashkirian-aged Cumberland Group, unconformably on older Mississippian sedimentary basins, or unconformably on crystalline basement rocks. The Minto Formation sits at the base of the Pictou Group, within the New Brunswick Platform in the Marysville Subbasin (Dyer, 1926; Muller, 1951; St. Peter and Johnson, 2009). Muller (1951) renamed the Grand Lake Formation of Dyer (1926) to the Pictou Group of Bell (1944) and upgraded the Minto, Hurley Creek, and Sunbury Creek members of the Grand Lake Formation to formation status.

The Minto Formation is defined as a $200-230 \mathrm{~m}$ thick section of grey to reddish brown and locally maroon sediments that are exposed in central New Brunswick (Dyer, 1926; Muller, 1951). Palynomorph assemblages analysed by Haquebard and Barss (1970) and Haquebard (1972) indicated that the Minto Formation belongs to the Vestispora Palynomorph Zone, which is of Westphalian C (Moscovian) age, this corroborating the palaeobotany work of Bell (1962). 
The Hurley Creek Formation was defined as a $45-60 \mathrm{~m}$ thick stratigraphic package containing abundant red beds that have a coarsening upwards nature. Lithologies are dominantly red and grey mudstones with fine-grained sandstones in the lower strata and red (locally green-grey) course feldspathic and lithic sandstones with polymictic conglomerates in the upper strata (Muller, 1951). Finally, the overlying Sunbury Creek Formation was estimated to have a maximum thickness of approximately $90 \mathrm{~m}$ and has similar lithologies to the basal Minto Formation (Muller, 1951). This similarity resulted in St. Peter and Johnson (2009, and earlier references therein) informally incorporating the Sunbury Creek into the Minto Formation and downgrading the Hurley Creek Formation to member status. The stratigraphic descriptions of Muller (1951) are followed here.

The specimen NBMG 21589, which is the focus of the current account, was discovered at Robertson Point (Grand Lake, New Brunswick), where a coastal outcrop extends for a distance of $860 \mathrm{~m}$, between $45^{\circ} 52^{\prime} 12.52^{\prime \prime} \mathrm{N}$ and $45^{\circ} 52^{\prime} 4.76^{\prime \prime} \mathrm{W}$ (Figs. 3, 4). The lower strata are exposed along the east end of the outcrop. A thickness of up to $\sim 6 \mathrm{~m}$ of maroon to buff coloured, fine-grained sandstones are deposited in backfilled channel thalwegs that locally incise, or are lateral to, red to maroon mudstones and siltstones that represent interdistributary floodplain deposits with localized palaeosols. Detailed palynology studies have been attempted on these red-bed strata with little success (Duncan McLean and David Bodman, personal communication to Matthew R. Stimson, 2021) and volcanic ash beds are absent. Macrofloral elements of Cordaites principalis, Calamites sp. and cf. Pecopteris suggest a Pennsylvanian age and are consistent with previous workers descriptions of the Hurley Creek Formation fossil content (Muller, 1951). These strata are thus interpreted and mapped as belonging to the Hurley Creek Formation.

This basal red-bed unit is disconformably overlain by $\sim 12 \mathrm{~m}$ of dominantly grey to buff unit that is in erosive contact with the underlaying strata. The contact between the two units is exposed for $\sim 500 \mathrm{~m}$ along much of the shoreline outcrop due to a very shallow strike and dip of 150/5 SW. The disconformable overlaying strata are interpreted as belonging to the Sunbury Creek Formation (Muller, 1951; Allen et al., 2020) and is the stratigraphic equivalent to the uppermost strata of the Minto Formation according to St. Peter and Johnson (2009, and earlier references therein). At Robertson Point, the Sunbury Creek Formation strata are composed of a basal $\sim 6 \mathrm{~m}$ thick extraformational polymictic conglomeratic unit with localized coarse sandstone lenses. These strata locally incise the underlaying red bed Hurley Creek Formation up to $2 \mathrm{~m}$ deep. The conglomerates are overlain by $2.5 \mathrm{~m}$ of buff-coloured coarse to very fine sandstones that locally exhibit trough cross-bedding and sheet sandstone beds. The basal portion of this sandstone locally contains reworked pebbles derived from the underlaying conglomerate. This unit locally incises into the underlaying conglomerates up

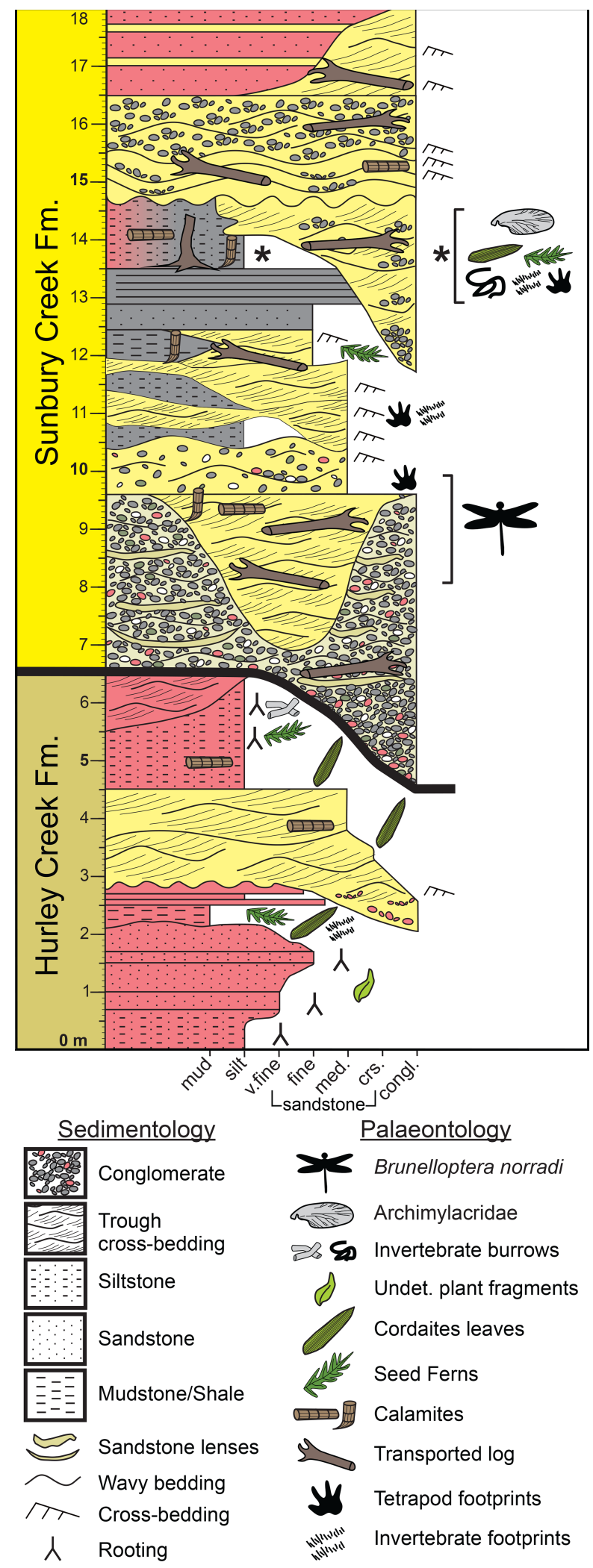

Figure 4. Stratigraphic section of uppermost Hurley Creek Formation $(6.5 \mathrm{~m})$ and lowermost Sunbury Creek Formation $(11.5 \mathrm{~m})$ strata exposed at the Robertson Point outcrop along the shoreline of Grand Lake (New Brunswick). 
to an additional $2.5 \mathrm{~m}$ that can be traced along the wave cut platform from the main fossil locality, past the odonate wing locality to the end of the outcrop to the west. The specimen NBMG 21589 was discovered as a float on the beach adjacent to its originating outcrop in this sandstone unit at roughly $45^{\circ} 52^{\prime} 9.86^{\prime \prime} \mathrm{N}, 66^{\circ} 5^{\prime} 43.14^{\prime \prime} \mathrm{W}$, exposed as a shallow coastal outcrop on the lake's wave cut platform. The sandstone unit is locally incised by a $2 \mathrm{~m}$ heterolithic and interbedded, very fine, trough cross-bedded sandstone and siltstone/mudstone shale. A fossil-rich unit is located between 12.0 and $15.0 \mathrm{~m}$ from the base of the measured section. It is composed of a $3 \mathrm{~m}$ of grey (laterally grades to maroon coloured) siltstone and shale and was found to contain abundant well-preserved plant fossils, abundant vertebrate and invertebrate ichnofossils, and a yet undescribed forewing of an Archimylacridae (i.e. a stem relative of cockroaches and mantids). These strata are interpreted to represent interdistributary floodplains.

Further above, the fossil bearing shales are incised by $4.5 \mathrm{~m}$ of channel bodies composed of coarse-grained buff to grey extraformational polymictic conglomerates and coarsegrained sandstones. These channels preserve abundant carbonized plant stems. Incising channels are composed of sandstone and conglomerate which are resistant to erosion compared to the laterally deposited shales. These channel deposits form localized coastal headlands where the shales have been eroded deeper along the shoreline and expose the sandstone channel margins in the cliff face. Incising and overlaying channel deposits measure up to $6.5 \mathrm{~m}$ in thickness (including $3 \mathrm{~m}$ incisions into underlaying strata). A localized $1.5 \mathrm{~m}$ thick maroon-coloured mudstone-filled channel with $5-10 \mathrm{~cm}$ very fine sandstone lenses incises the uppermost sandstone units.

The Pictou Group spans much of the latest Pennsylvanian and earliest Permian periods (St. Peter and Johnson, 2009, and references therein). The Minto Formation is thought to be of latest Bashkirian age, while the overlaying Hurley Creek Formation straddles the BashkirianMoscovian boundary. The overlaying Sunbury Creek Formation has traditionally been considered to be allostratigraphically of Moscovian age (St. Peter and Johnson, 2009). With the lack of volcanic rocks or ash beds throughout these formations, samples were collected for palynology analysis. Grey-shale samples were collected from $14 \mathrm{~m}$ above the base of the measured section and were processed for palynomorph analysis. Duncan McLean and David Bodman (personal communication to Matthew R. Stimson, 2021) analysed for palynomorphs and determined the palynomorph assemblage at Roberson Point to belong to the Torispora biozone. The miospore assemblage was dominated by the palynomorph Calamospora spp. with subdominate palynomorphs of Florinites pumicosus and Punctatisporites spp. The age determination was based on the presence of the palynomorph Vestispora fenestrate and Thymospora pseudothiessenii?. The Robertson Point outcrop can be considered of earliest Moscovian age (i.e. early Westphalian C), which confirms previous age assessments of the Sunbury Creek Formation. This proposal is further corroborated by the undescribed Archimylacridae, which points towards a late Westphalian B to early Westphalian $\mathrm{C}$ age.

\section{Comparative analysis}

To ease the systematic placement of the new species described below, we carried out a survey of the configurations involving MP, the cubital system, and AA in early stem Odonata (Fig. 5), inspired from Riek and KukalováPeck (1984) and Brauckmann and Zessin (1989), and considering recent discoveries. The wing morphology of $E \mathbf{E}$ geropteron lunatum is widely regarded as a ground plan for the entire Odonata. As far as MP, the cubital system, and AA are concerned, it is characterized by the absence of fusion between MP and $\mathrm{CuA}$, between $\mathrm{CuA}$ and $\mathrm{CuP}$ (after both veins had diverged), and between $\mathrm{CuP}$ and AA (Fig. 5a). Instead, in each instance, the involved veins are connected by a short cross-vein. At the point of connection with these crossveins, veins commonly form a sharp angle. The morphology of Erasipteron larischi Pruvost, 1933 (based on original description, Brauckmann and Zessin, 1989, and a new photograph of the holotype (bearing the specimen number MB.I.455, Museum für Naturkunde Berlin), Andreas Abele, personal communication to Olivier Béthoux, 2020), known from a single forewing, is schematized in Fig. 5c. With respect to the previous configuration, it is the outcome of multiple fusions (Fig. 5b), whose sequence of acquisition is not evident. The case is straightforward if considering the holotype of Argentinala cristinae Petrulevičius and Gutiérrez, 2016, in which both wing pairs lack the $\mathrm{CuP}+\mathrm{AA}$ fusion, suggesting that it was acquired last. This specimen also suggests that a delayed acquisition of derived conditions in the hindwing, with respect to the forewing, is a plausible phenomenon: while MP and $\mathrm{CuA}$ are fused for a long distance in the forewing, these two veins are only connected (or briefly connected) in the hindwing, and $\mathrm{CuA}$ and $\mathrm{CuP}$ are briefly fused in the forewing, but remain distinct in the hindwing. This configuration suggests that the first fusion to occur was the $\mathrm{MP}+\mathrm{CuA}$ one, as it is the only fusion shared by both wing pairs. It follows that the $\mathrm{CuA}+\mathrm{CuP}$ fusion came second. This acquisition sequence $(\mathrm{MP}+\mathrm{CuA}$, then $\mathrm{CuA}+\mathrm{CuP}$, then $\mathrm{CuP}+\mathrm{AA}$ ) is supported by the configuration in both Kirchnerala treintamil Petrulevičius and Gutiérrez, 2016 and Aulertupus tembrocki Zessin and Brauckmann, 2010, each known from a forewing in which the $\mathrm{CuP}+\mathrm{AA}$ fusion is lacking, while the two others are present. However, a notable exception is Geropteron arcuatum, in which the only fusion to lack is the MP $+\mathrm{CuA}$ one. The scheme represented in Fig. 5c corresponds to a taxon that can be characterized as displaying the derived character state "occurrence of a MP $+\mathrm{CuA}$ fusion, of a $\mathrm{CuA}+\mathrm{CuP}$ fusion (after both 
(a)

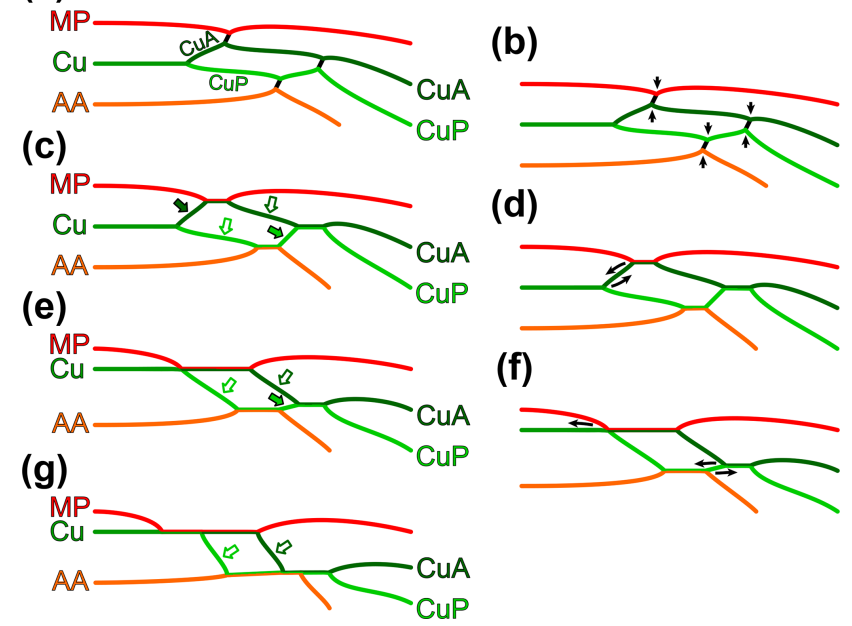

Figure 5. Transformation series of the relation between MP (red), the cubital system (green) and AA (orange) in early stem Odonata: $(\mathbf{a}, \mathbf{c}, \mathbf{e}, \mathbf{g})$ schemes and $(\mathbf{b}, \mathbf{d}, \mathbf{f})$ transformations allowing transition from one scheme to another; (a) condition in Eugeropteron lunatum Riek in Riek and Kukalová-Peck (1984), considered as ground plan; (b) transformation from (a) to (c), MP and $\mathrm{CuA}$ fuse, $\mathrm{CuA}$ and $\mathrm{CuP}$ fuse (after they had first diverged), and $\mathrm{CuP}$ and AA fuse; (c) condition in Erasipteron larischi Pruvost, 1933, Brunellopteron norradi Béthoux, Deregnaucourt and Norrad gen. et sp. nov. (darkgreen-filled arrow indicates the basal free portion of $\mathrm{CuA}$, basal to its fusion with MP; dark-green-bordered arrow indicates the median free portion of $\mathrm{CuA}$; light-green-bordered arrow indicates the basal free portion of $\mathrm{CuP}$; light-green-filled arrow indicates the median free portion of $\mathrm{CuP})$; (d) transformation from (c) to (e), the point of fusion of MP and $\mathrm{CuA}$ reaches the point where $\mathrm{CuA}$ and $\mathrm{CuP}$ diverge, with the consequence that $\mathrm{CuA}$ has no basal free portion (dark-green-filled arrow in c); (e) condition in Namurotypus sippeli Brauckmann and Zessin, 1989; (f) transformation from (e) to (g), the point of fusion of MP with the cubital system is relocated further basally, and the fusion of AA and CuP continues beyond the point where $\mathrm{CuA}$ and $\mathrm{CuP}$ fuse, with the consequence that $\mathrm{CuP}$ has no median free portion; (g) condition in Meganeura-like species.

veins had first diverged) and of a $\mathrm{CuP}+\mathrm{AA}$ fusion" (as opposed to "in both wing pairs, MP and $\mathrm{CuA}$ distinct, $\mathrm{CuA}$ and $\mathrm{CuP}$ distinct, and/or CuP and AA distinct)", applying to both wing pairs.

In both wing pairs, Namurotypus sippeli Brauckmann and Zessin, 1989 displays a MP $+\mathrm{CuA}$ fusion extending more basally than in the species considered above. This is best documented based on the holotype (specimen P28957 WMNM - formerly $\mathrm{N} \mathrm{1000),} \mathrm{in} \mathrm{which} \mathrm{MP} \mathrm{fuses} \mathrm{with} \mathrm{Cu}$ at the point where $\mathrm{CuA}$ and $\mathrm{CuP}$ diverge (as represented in Fig. 5e) in the forewing, and shortly after it in the hindwing (based on original description and new photographs, Lothar Schöllmann, personal communication to Olivier Béthoux, 2021). As a consequence, the basal free portion of $\mathrm{CuA}$ (dark-greenfilled arrow on Fig. 5c) no longer occurs (Fig. 5e), at least in the forewing. Concurrently, this species retains, in both wing pairs, the free portion of $\mathrm{CuP}$ occurring distal to the $\mathrm{CuP}-\mathrm{AA}$ split and basal to its fusion with $\mathrm{CuA}$ (hereafter "median free portion of CuP"; light-green-filled arrows on Fig. 5c, e). As pointed out by Nel et al. (2009), the further completion of the fusion of MP with $\mathrm{Cu}$ is apparently highly homoplastic among Palaeozoic and Triassic stem Odonata. The scheme represented in Fig. 5e corresponds to a taxon that can be characterized as displaying the derived character state "MP fused with the cubital system at the point where $\mathrm{CuA}$ and $\mathrm{CuP}$ diverge, or basal to it" (as opposed to "MP fused with the cubital system distal to the point where $\mathrm{CuA}$ and $\mathrm{CuP}$ diverge"), applying to both wing pairs.

The configuration in Erasipteroides valentini Brauckmann in Brauckmann et al. (1985) differs only slightly from that of Namurotypus sippeli. In the specimen P26133 WMNM (based on Bechly et al., 2001, and new photographs, Lothar Schöllmann, personal communication to Olivier Béthoux, 2021), presumably belonging to this species, both fore- and hindwing conform to the configuration represented in Fig. 5e. Note that in the holotype (specimen P30361 WMNM) the CuP + AA fusion extends slightly beyond the point where $\mathrm{CuA}$ fuses with $\mathrm{CuP}$, with the consequence that $\mathrm{CuP}$ has no free median portion (based on new photographs, Lothar Schöllmann, personal communication to Olivier Béthoux, 2021).

The configuration in Erasipterella jini (Zhang, Hong and $\mathrm{Su}$ in Su et al., 2012) (see original description and $\mathrm{Li}$ et al., 2013), known from both fore- and hindwings, suggests that the extension of the $\mathrm{MP}+\mathrm{CuA}$ fusion (into a $\mathrm{MP}+\mathrm{Cu} / \mathrm{CuA}$ fusion) was acquired before that of the $\mathrm{CuP}+\mathrm{AA}$ fusion (into a $(\mathrm{CuP} / \mathrm{CuA}+\mathrm{CuP})+\mathrm{AA}$ fusion; Fig. 5f). While no traces of the free basal portion of MP are present in this species (i.e. MP is fully fused with $\mathrm{Cu}$ from the wing base or close to it), several of the known hindwings retain a free median portion of $\mathrm{CuP}$. In other words, as far as $\mathrm{AA}$ and $\mathrm{CuP} / \mathrm{CuA}+\mathrm{CuP}$ are concerned, it conforms to the scheme represented in Fig. 5e. Concurrently, the forewing of Erasipterella jini displays the "extended version" of the $\mathrm{AA}+\mathrm{CuP}$ fusion, resulting in a loss of the free median portion of $\mathrm{CuP}$, as represented in Fig. $5 \mathrm{~g}$ (with the possible exception of the holotype). Note that, besides information on the sequence of character state acquisitions, this species composes another example suggesting that derived traits were acquired first in the forewing and later in the hindwing in the early evolution of Odonata.

Most Meganeura-like species display the configuration represented in Fig. 5g (Nel et al., 2009; Li et al., 2013; Zessin, 1983; among others). Megatypus schucherti (Fig. 1c, f) is peculiar in that the median free portion of $\mathrm{CuA}$ and the basal free portion of $\mathrm{CuP}$ (dark- and light-green-bordered arrows, respectively, in Fig. 5c, e, g) are fused. The scheme represented in Fig. 5g corresponds to a taxon that can be characterized as displaying the derived character state "AA fused with the cubital system until the point where the free median portions of $\mathrm{CuA}$ and $\mathrm{CuP}$ fuse, or distal to it" (as opposed 
to "AA diverging from $\mathrm{CuP}+\mathrm{AA}$ basal to the point where the free median portions of $\mathrm{CuA}$ and $\mathrm{CuP}$ fuse"), applying to both wing pairs.

Relevant character states having been identified, a systematic framework based on these could have been elaborated by resorting to cladotypic nomenclature or PhyloCode apomorphy-based definitions. However, it proved difficult to find appropriate reference specimens (cladotypes or internal specifiers). Most importantly, the apparent heterobathmy of character state acquisition between fore- and hindwings would have required character state labels to mention the particular organ(s) of concern (viz. "in both wings pairs" or "at least in forewing"). However, this option was difficult to implement because the morphologies of both fore- and hindwing bases are known in very few species of early stem Odonata. Another consequence of this lack of data is that the actuality of the "forewing antecedence" phenomenon is yet to be further verified. Additionally, some degree of intraspecific variability is to be expected, making it hazardous to designate species known from a very limited material as reference. Finally, the basal free portions of $\mathrm{CuA}$ and $\mathrm{CuP}$ (green-bordered arrows on Fig. 5c, e, g) can prove difficult to locate in Meganeura-like species, where they tend to resemble cross-veins. In turn, it makes it difficult to assess the position of AA with respect to them, necessary to qualify the presence of the configuration represented in Fig. 5g.

\section{Systematic description}

Order Odonata Fabricius, 1793

Taxon Neodonatoptera Bechly, 1996

Family incertae sedis

Brunellopteron Béthoux, Deregnaucourt and Norrad gen. nov.

(urn:1sid:zoobank.org:act:1627CA27-D582-441E87AA-4F8FA71E354E)

\section{Type species}

Brunellopteron norradi Béthoux, Deregnaucourt and Norrad sp. nov.

\section{Gender}

Masculine.

\section{Etymology}

The genus name honours Paul-Michael Brunelle (19522020), an odonatologist who contributed greatly to our knowledge on odonate biodiversity in the Atlantic Canadian region (see McAlpine, 2020).

\section{Diagnosis}

By monotypy, as for the type species.

\section{Discussion}

Based on delimitations given by Bechly et al. (2001) the type species of the new genus can be assigned to the taxon Neodonatoptera. Within this taxon, the lack of an archaedictyon, one of the proposed apomorphies of the taxon $\mathrm{Eu}-$ odonatoptera and present in the new material, would require a reappraisal. Notably, (i) the lack of an archaedictyon is regarded as homoplastic, and (ii) the occurrence of an archaedictyon among stem Odonata, in particular in Erasipteron larischi, is not evident. Moreover, according to Bechly et al. (2001), the monophyly of the taxon regarded as a sister group of Euodonatoptera, namely Eomeganisoptera (including the Erasipteridae), remains to be verified. The length of $\mathrm{ScP}$ has also been regarded as a relevant character by Bechly et al. (2001), but (i) it is possibly homoplastic and (ii) it is difficult to evaluate in the available material of the type species of the new genus. Considering that all Euodonatoptera conform to one of the conditions represented in Fig. 5e and g, and that the type species of the new genus does not (it conforms to the condition represented in Fig. 5c), we propose to exclude the new genus from this taxon.

Brunellopteron norradi Béthoux, Deregnaucourt and Norrad, sp. nov.

(urn:lsid:zoobank.org:act:F29F7AC2-5624-4786-

B842-7CD22C0E4B3E)

(Figs. 6, 7)

\section{Material}

Holotype, specimen NBMG 21589, a positive imprint of a left hindwing, deposited at the New Brunswick Museum (palaeontology collection; Saint John, New Brunswick, Canada).

\section{Etymology}

The species epithet composes a dedication to Donald B. Norrad, co-discoverer of the holotype (and father of the second author).

\section{Diagnosis}

Hindwing: area between anterior wing margin and $\mathrm{ScP}$ broad; MP branched, or area between MP and CuA filled with alternating convex and concave intercalaries; several cross-veins connecting (i) MP and the median free portion of $\mathrm{CuA}$, (ii) the basal free portion of $\mathrm{CuA}, \mathrm{MP}+\mathrm{CuA}$ and the median free portion of $\mathrm{CuA}$ on one hand, and the basal free portion of $\mathrm{CuP}$ on the other, and (iii) the basal free portion of $\mathrm{CuP}$ and $\mathrm{AA}$; area between $\mathrm{AA}$ and the posterior wing 
(a)

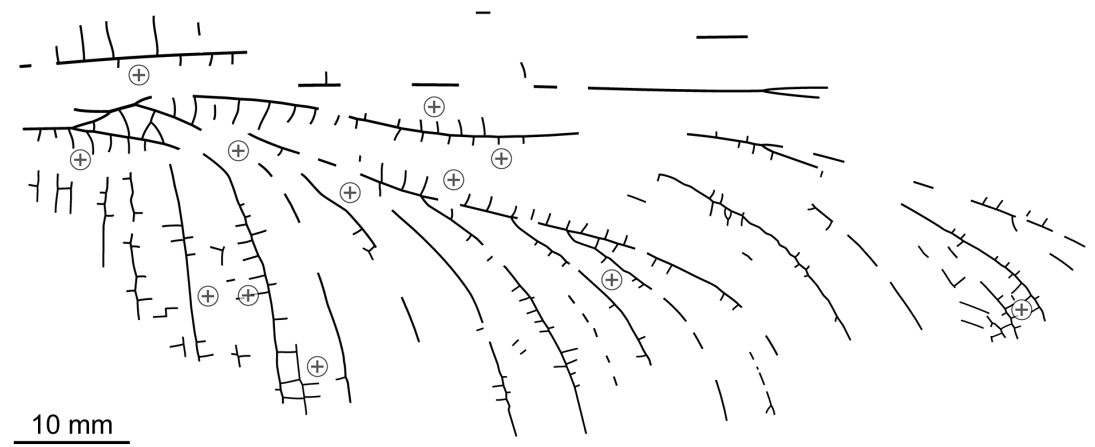

(b)

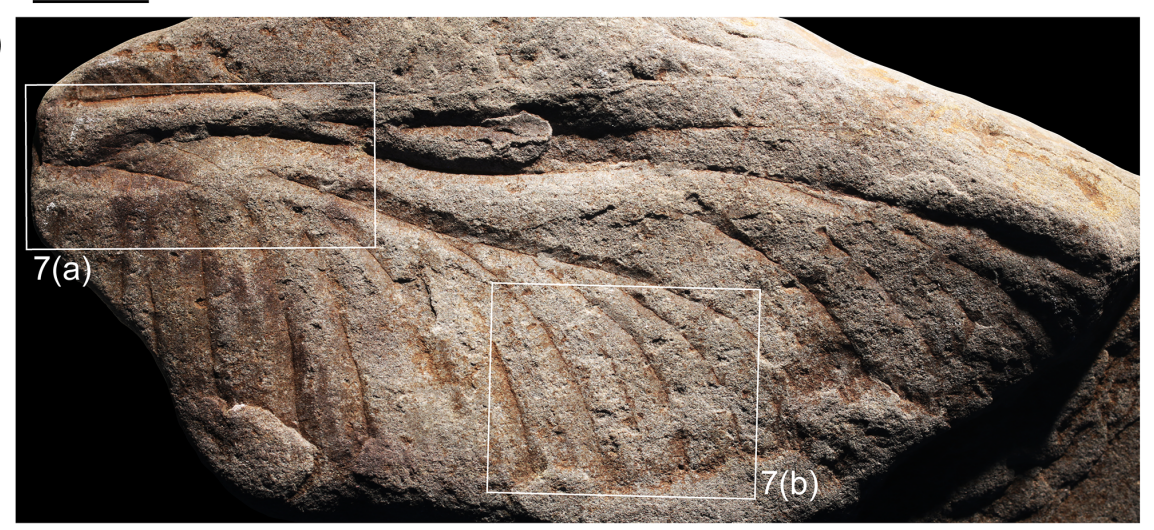

(c)

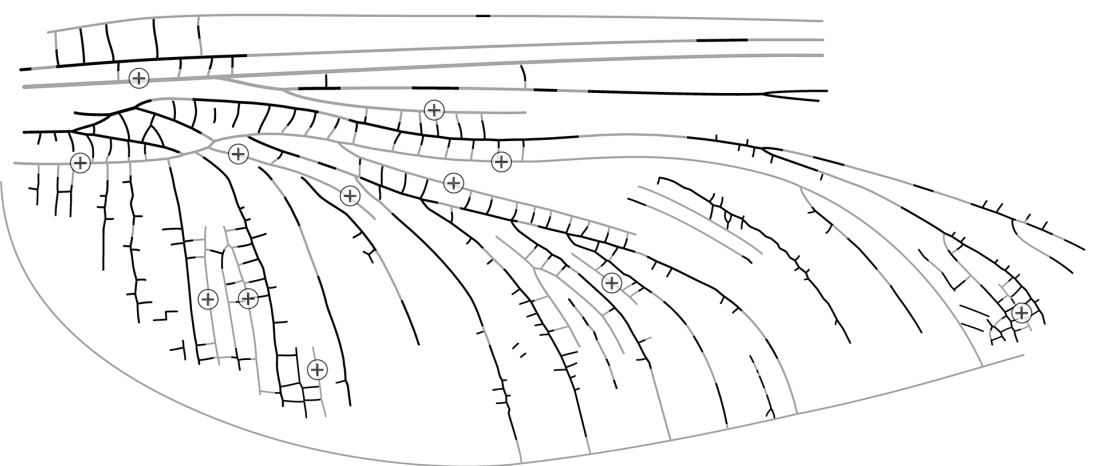

(d)

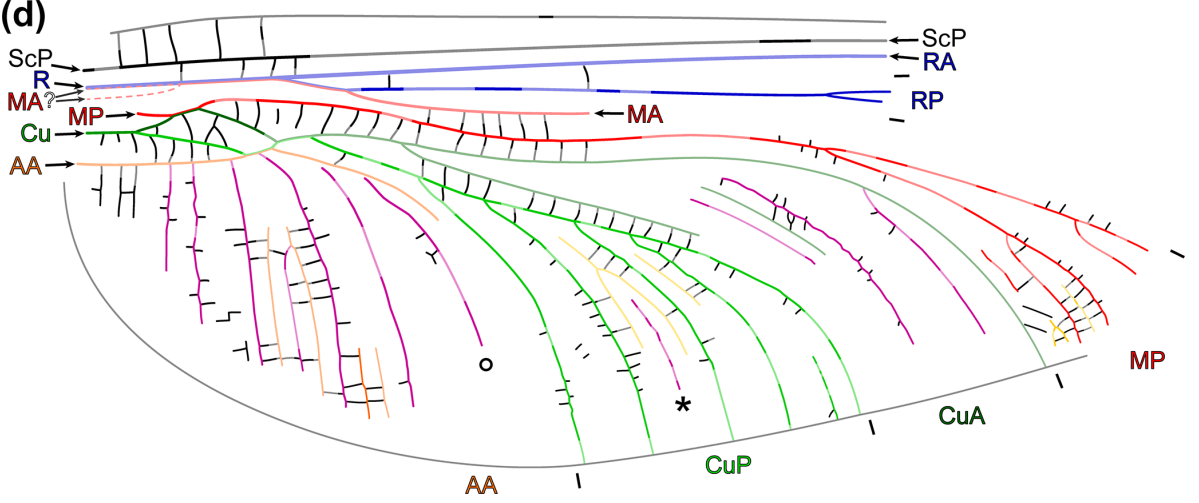

Figure 6. Brunellopteron norradi Béthoux, Deregnaucourt and Norrad gen. et sp. nov., holotype (NBMG 21589, New Brunswick Museum; positive imprint of a left hindwing): (a) drawing of visible structures, with indication of convex, weathered portions; (b) photograph (dryethanol composite, flipped horizontally), with indication of the location of items in Fig. 7; (c) same as in (a) but with portions reconstructed based on convex, weathered portions and the morphology of known related species; (d) same as in (c) with colour-coding and legend ( ${ }^{\circ}$ indicates a particular concave intercalary vein; see text; $*$ indicates an intercalary of second order). 

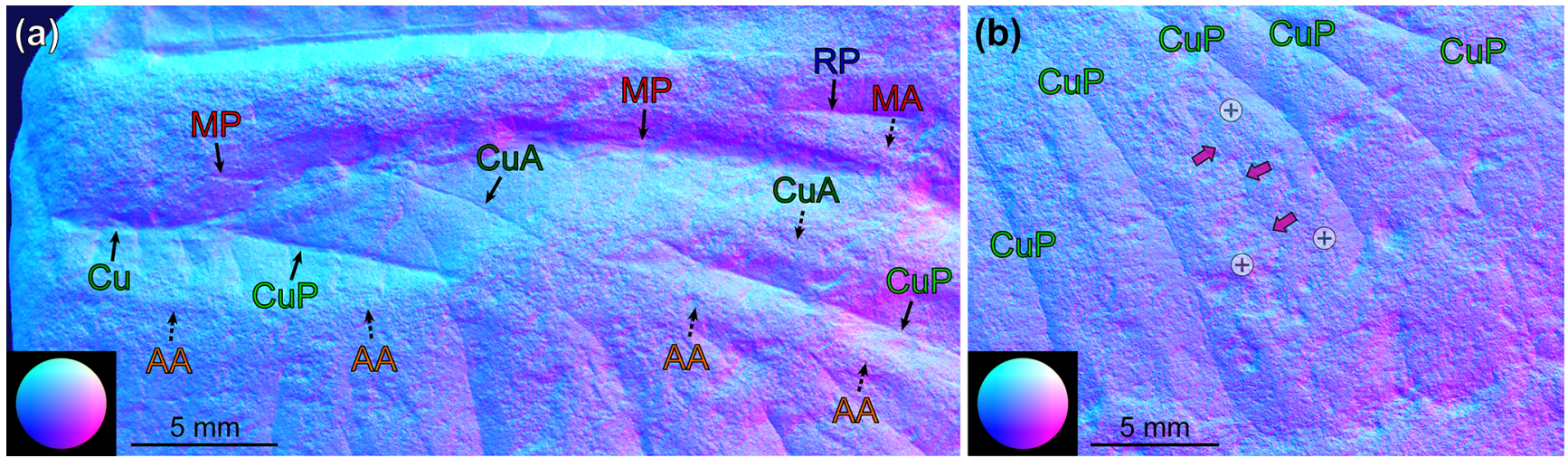

Figure 7. Brunellopteron norradi Béthoux, Allen, Norrad and Deregnaucourt gen. et sp. nov., holotype (NBMG 21589, New Brunswick Museum; positive imprint of a left hindwing), details as located in Fig. 6b, RTI extracts, normals visualization (all flipped horizontally; bottom left corners, normals visualization colour code as applied to a hemisphere): (a) basal area; (b) detail of the concave intercalary of second order (purple arrows) located between $\mathrm{CuP}$ branches.

margin well developed, filled with numerous concave intercalary veins; occurrence of intercalaries of second order (i.e. having the same elevation as that of the main vein delimiting the corresponding area).

\section{Description}

Holotype specimen (NBMG 21589): basal half of a hindwing, positive imprint, most convex veins eroded; length about $93 \mathrm{~mm}$ as preserved, $145-155 \mathrm{~mm}$ as estimated; maximum width $36.9 \mathrm{~mm}$ as preserved, $38.6 \mathrm{~mm}$ as estimated; area between anterior wing margin and $\mathrm{ScP}$ broad in basal area; R (or R + MA) not preserved but position of basal portion inferable based on slope elevation; course of basal portion of MA not preserved, either fused with $\mathrm{R}$ from the wing base or more distally (dotted lines in Fig. 6d); origin of RP + MA and split of this vein (into RP and MA) not preserved; RP rectilinear, with a fork about $66 \mathrm{~mm}$ distal to wing base; MA (distal to the RP-MA split) not preserved but a short portion of its course, opposite the posterior bending of MP, inferable based on slope elevation; MP fusing with $\mathrm{CuA}$ for $2.3 \mathrm{~mm}$, then diverging from $\mathrm{MP}+\mathrm{CuA}$ somewhat obliquely, directed anteriorly; then, MP with a marked posterior arching, inflexion point $27.5 \mathrm{~mm}$ distal of the MP$\mathrm{CuA}$ split; first MP fork (or, first concave intercalary arising) $54.3 \mathrm{~mm}$ distal of the MP-CuA split; area between the anterior stems of MP and $\mathrm{CuA}$ broad; $\mathrm{Cu}$ with a distinct basal stem splitting into $\mathrm{CuA}$ and $\mathrm{CuP}$; $\mathrm{CuA} 3.5 \mathrm{~mm}$ long before it fuses with MP; $\mathrm{CuA}$ portion distal to the split of $\mathrm{MP}+\mathrm{CuA}$ (into $\mathrm{MP}$ and $\mathrm{CuA}$ ) about $7.4 \mathrm{~mm}$ long before it fuses with $\mathrm{CuP}$ (itself emerging from $\mathrm{CuP}+\mathrm{AA}$ ); $\mathrm{CuA}+\mathrm{CuP}$ fusion about $3.0 \mathrm{~mm}$ long; distal to the $\mathrm{CuA}-\mathrm{CuP}$ split, courses of the anterior stem of $\mathrm{CuA}$ and of its first posterior branch inferable based on slopes elevations; anterior-most branch of $\mathrm{CuA}$ with a posterior arching, more or less opposite to that of MP; basal portion of $\mathrm{CuP} 9.7 \mathrm{~mm}$ long before it fuses with
$\mathrm{AA}$; CuP presumably with a short free portion distal to the $\mathrm{CuP}-\mathrm{AA}$ split and basal to its fusion with $\mathrm{CuA}$; $\mathrm{CuP}$ posteriorly pectinate, with 5 terminal branches; course of the anterior stem of AA inferable, to some extent, based on slopes elevation; AA fused with $\mathrm{CuP}$ for about $2.0-2.5 \mathrm{~mm}$; in the area between $\mathrm{AA}$ and the posterior wing margin, course of actual AA branches barely preserved; cross-venation generally scalariform, forming intercalary veins of elevation opposed to that of surrounding main veins, at least within the $\mathrm{CuA}, \mathrm{CuP}$ and $\mathrm{AA}$ areas; MP and median free portion of $\mathrm{CuA}$, median free portion of $\mathrm{CuA}$ and basal free portion of $\mathrm{CuP}$, and basal free portion of $\mathrm{CuP}$ and $\mathrm{AA}$ connected by several cross-veins; at least in the $\mathrm{CuP}$ area, occurrence of an intercalary vein of second order (bordered by two intercalary veins; $*$ in Fig. 6d).

\section{Locality and horizon}

Robertson Point, Grand Lake, New Brunswick, Canada; Sunbury Creek Formation.

\section{Discussion}

The nearly complete lack of preserved convex elements (main veins or intercalaries), a consequence of weathering, could be partly circumvented by considering the elevation of the preserved slopes. For example, the course of the basal portion of AA can be easily traced (Fig. 7a). The reconstruction of the course of AA distal to its fusion with $\mathrm{CuP}$ was elaborated considering that the concave element indicated by $\circ$ on Fig. 6d is separated from CuP by an elevated section (Fig. 7a), and therefore it cannot be a branch of CuP. It is therefore a concave intercalary branch located within the AA area. It follows that the elevated section must be AA. Then, given the orientation of the basal and inferred distal portions of AA, the occurrence of a short, free portion of $\mathrm{CuP}$ (emerging from $\mathrm{CuP}+\mathrm{AA}$ and basal to its fusion with $\mathrm{CuA}$ ) was in- 
ferred, but its reconstructed length is speculative. The course of several other portions of convex elements remains more or less speculative. Notably, whether MA fuses with R at the wing base, or more distally, cannot be appreciated. In some cases, conditions known in related species allowed plausible reconstruction, such as the length of the RP + MA stem. Finally, portions of a concave element were observed between genuine $\mathrm{CuP}$ branches $(*$ on Fig. 6d; purple-filled broad arrows on Fig. 7b). It is delimited by two elevated areas, interpreted as remains of convex intercalaries. It follows that this concave structure is an intercalary sharing the same elevation as that of the main vein delimiting the corresponding area (here, $\mathrm{CuP}$ ), this qualifying an intercalary of second order. The occurrence of a comparatively broad area between AA and the posterior wing margin makes it patent that it is a hindwing.

Based on the above, the new specimen displays the configuration schematized in Fig. 5c. Specifically, it displays the derived character state "occurrence of a MP $+\mathrm{CuA}$ fusion, of $\mathrm{a} \mathrm{CuA}+\mathrm{CuP}$ fusion (after both veins had first diverged) and of a CuP + AA fusion" (as opposed to "in both wing pairs, $\mathrm{MP}$ and $\mathrm{CuA}$ distinct, $\mathrm{CuA}$ and $\mathrm{CuP}$ distinct, and/or $\mathrm{CuP}$ and AA distinct"). As a consequence, close relationships with the following species can be excluded: Eugeropteron lunatum, Geropteron arcuatum, Tupacsala niunamenos Petrulevičius and Gutiérrez, 2016, Kirchnerala treintamil, and Aulertupus tembrocki. Conversely, the new species clearly displays a basal free portion of $\mathrm{CuA}$ (dark-green-filled arrow on Fig. 5c), a plesiomorphy indicating that close relationships with Erasipteroides valentini and Euodonatoptera (as delimited by Bechly et al., 2001) can be excluded.

The remaining species are Erasipteron larischi, known from a single forewing whose apex is missing, and Zessinella siope Brauckmann, 1988, known from body remains associated with fore- and hindwings whose venation could be deciphered at their bases only. Piesbergtupus hielscheri Zessin, 2006, known from the basal half of a single forewing, is also considered as it likely displays a free median portion of $\mathrm{CuP}$ and, possibly, a free basal portion of $\mathrm{CuA}$ (Fig. 8). The same applies to Gallotupus oudardi Nel, Garrouste and Roques, 2008, known from a single, almost complete forewing, creased in several areas.

Erasipteron larischi and Zessinella siope are herein regarded as essentially similar. Both species have a similar size (forewing about $15 \mathrm{~mm}$ wide in the former, about $9 \mathrm{~mm}$ in the latter), comparatively large cells, and a very short $\mathrm{CuP}+\mathrm{AA}$ fusion (at least in the forewing). The main difference is, in the forewing, the number of rows of cells in the area between AA and the posterior margin (two in the former, one in the latter), a trait which could be a mere consequence of the size difference. Interestingly, while the three typical fusions ( $\mathrm{MP}+\mathrm{CuA}, \mathrm{CuA}+\mathrm{CuP}$ and $\mathrm{CuP}+\mathrm{AA})$ occur in the forewing of Zessinella siope, it is not evident that it is the case in the hindwing, for which a possible interpretation is that $\mathrm{CuP}$ and $\mathrm{AA}$ are connected by a cross-vein. This should

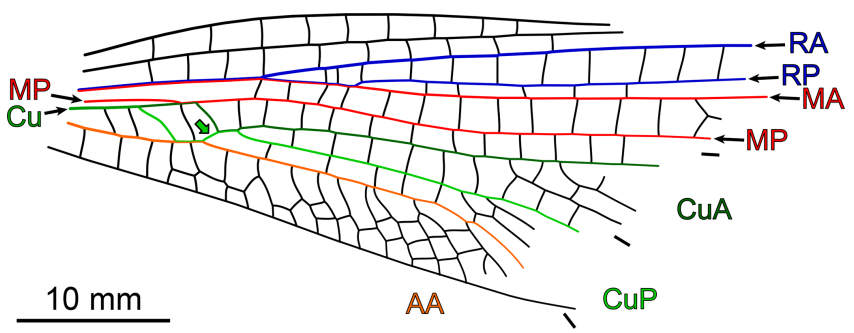

Figure 8. Piesbergtupus hielscheri Zessin, 2006, holotype (private collection), redrawn based on data in original description (as for $\mathrm{CuA}, \mathrm{CuP}$ and $\mathrm{AA}$, only the anterior stem colour-coded; lightgreen-filled arrow indicates the median free portion of $\mathrm{CuP}$ ).

be further investigated, but if this were the case, the new specimen would then strongly differ from Zessinella siope and, by extension, from Erasipteron larischi. Additionally, intercalary veins are absent in the area between AA and the posterior wing margin in the forewing of these two species (condition unknown in hindwing). Even though comparison with the new specimen is hindered by the fact that it is a hindwing, given the important development of intercalary veins in this area, it can be reasonably assumed that such structures occurred in the corresponding forewing. Notably, such intercalary veins occur in the known forewing of Gallotupus oudardi.

The occurrence of a seemingly branched MP in the new specimen is a very unusual feature among Odonata. This vein is simple in Erasipteron larischi (the distal half of MP is unknown in Zessinella siope and Piesbergtupus hielscheri) and in virtually all Odonata indeed. Among Euodonatoptera, the Permian and Triassic Zygophlebiida possess a wide area between MP and the anterior stem of CuA that is filled with alternating convex and concave vein-like structures. However, the latter, which could be regarded as MP branches, are believed to be intercalaries instead (see Nel et al., 2001, and references therein). Such organization can also be found in some extant forms, for example some Polythoridae (see Garrison et al., 2010). Then, it cannot be completely ruled out that it is also the case in the new specimen (i.e. that it possesses a simple MP and alternating convex and concave intercalaries between MP and $\mathrm{CuA}$ ). This condition might also be present in Gallotupus oudardi. Yet, the character state "area between MP and $\mathrm{CuA}$ broad, filled with intercalary veins" would allow differentiating the species the new specimen belongs to from Erasipteron larischi (and, by extension, Zessinella siope).

One of the peculiarities of Piesbergtupus hielscheri is the straight to slightly concave shape of its posterior wing margin in the basal third of the forewing (Fig. 8). In Odonata, but also in many Megasecopteromorpha, this trait is part of a petiolation syndrome that very generally occurs in both foreand hindwing. Judging from the development of the AA area in the new specimen, the species it belongs to most likely 
had forewings with a broad base or a very short petiole at best. This excludes close relationships with Piesbergtupus hielscheri. The new specimen is also larger than this species (estimated lengths $145-155 \mathrm{~mm}$ vs. $100 \mathrm{~mm}$ ).

It occurs that Gallotupus oudardi is possibly the closest relative of the species to which the new specimen belongs. Further comparison is made difficult because several critical areas are creased in the only known specimen of the former. In particular, the point where MP fuses with the cubital system (either with $\mathrm{CuA}$ or $\mathrm{Cu}$ ) is unknown. Judging from the distance between the point of fusion of $\mathrm{CuA}$ and $\mathrm{CuP}$ on one hand, and the first fork of RP on the other, preserved in both specimens, the new one is about 1.6 times as long as the known wing of Gallotupus oudardi, this precluding an assignment of the new specimen to this species.

Finally, a trait absent in the species considered above is the occurrence of several cross-veins connecting (i) MP and the median free portion of $\mathrm{CuA}$, (ii) the basal free portion of $\mathrm{CuA}, \mathrm{MP}+\mathrm{CuA}$ and the median free portion of $\mathrm{CuA}$ on one hand, and the basal free portion of $\mathrm{CuP}$ on the other, and (iii) the basal free portion of CuP and AA (Figs. 6, 7a). This trait is present in Aulertupus tembrocki, presumably remotely related to the species the new specimen belongs to, as it lacks the $\mathrm{CuP}+\mathrm{AA}$ fusion (see above).

Observed differences between the new specimen and known species legitimate the erection of a new species and of a new genus.

\section{Conclusions}

Brunellopteron norradi belongs to a subset of early stem Odonata known from very few species, themselves known from few and mostly incomplete specimens. The corresponding material was recovered from western European localities of Moscovian age (Westphalian C/D), which corroborates the age of the Robertson Point outcrop as deduced from palynomorph content. Despite its incompleteness, the new species remains a useful addition to our knowledge of the early evolution of Odonata wing venation, owing to its unique combination of character states. In particular, it is the only Erasipteron-like species to possess such an important development of intercalary veins, more typical of the large Meganeura-like griffinflies, most of which occur in strata younger than the Moscovian.

Data availability. The new material included in the paper is accessible and deposited at the New Brunswick Museum (palaeontology collection; Saint John, New Brunswick, Canada), and all data are included in the description. RTI files from which images reproduced in Fig. 7 were extracted are available from https://doi.org/10.5061/dryad.fttdz08s0 (Béthoux et al., 2021).
Author contributions. OB and MRS elaborated the project. All authors contributed to redacting the current account: OB as main contributor of the comparative analysis section; OB and ID as main contributors of the systematic section (including specimen documentation and preparation of illustrations); MRS, OAK, LFA, REN, and $\mathrm{SJH}$ as main contributors of the geological context section. LFA and REN contributed to collecting the new material.

Competing interests. The authors declare that they have no conflict of interest.

Disclaimer. Publisher's note: Copernicus Publications remains neutral with regard to jurisdictional claims in published maps and institutional affiliations.

Acknowledgements. We are grateful to the referees and the editorial board of Fossil Record for their constructive comments. We are also grateful to Susan Butts (Yale Peabody Museum, New Haven, USA) for allowing a loan of fossil material she is in charge of and to Andreas Abele (Museum für Naturkunde, Berlin, Germany) and Lothar Schöllmann and Christoph Steinweg (LWLMuseum für Naturkunde, Münster, Germany) for providing photographs of fossil material they are in charge of. We are grateful to Donald B. Norrad for contributing the discovery of the new material. Matthew R. Stimson and Olivia A. King acknowledge Kathleen Thorne and Serge Allard for their financial support for this and other projects provided by the New Brunswick Geological Survey's Branch Research Grant. Olivia A. King would like to thank the Geological Survey of Canada (Denis Lavoie) for providing graduate school funding during the preparation of this article. Matthew R. Stimson and Olivia A. King thank Nancy Jacque, David Wagner, Christopher Taylor, and Marion Homer for their moral and/or financial support during the writing of this article. Adrian Park is thanked for insightful discussions related to the geological context section. The authors would like to thank Martin Montplaisir, Gregory MacInnis, and Jason Raworth for volunteering their time and equipment to photograph the fossil site with their DJI Mavic Air 2 Drone. Rowan E. Norrad and Luke F. Allen would like to thank the residents of Robertson Point for their continued support. Matthew R. Stimson would like to thank Donald McAlpine for providing insightful conversation and information related to the late Paul-Michael Brunelle.

Financial support. Matthew R. Stimson acknowledges the support of the Natural Sciences and Engineering Research Council of Canada (NSERC) (funding reference number 547631).

Review statement. This paper was edited by Torsten Scheyer and reviewed by Günter Bechly and one anonymous referee. 


\section{References}

Allen, L., Norrad, R., Stimson, M. R., King, O. A., Hinds, S. J., Park, A., and Calder, J. H.: The first discovery of an ichnofossil assemblage from the middle Pennsylvanian Minto Formation of central New Brunswick, Canada: implications for paleobiodiversity, Abstract to the 46th Colloquium \& Annual General Meeting 2020 of the Atlantic Geoscience Society, Atlantic Geol., 56, 2122, https://doi.org/10.4138/atlgeol.2020.002, 2020.

Ball, F. D., Sullivan, R. M., and Peach, A. R.: Carboniferous drilling project, New Brunswick Department of Natural Resources, Fredericton, Canada, 109 pp. +9 maps, 1981.

Bechly, G.: Morphologische Untersuchungen am Flügelgeäder der rezenten Libellen und deren Stammgruppenvertreter (Insecta; Pterygota; Odonata) unter besonderer Berücksichtigung der Phylogenetischen Systematik und des Grundplanes der Odonata, revised edition including appendix in English, Petalura, special volume 2, 1-402, 1996.

Bechly, G., Brauckmann, C., Zessin, W., and Gröning, E.: New results concerning the morphology of the most ancient dragonflies (Insecta: Odonatoptera) from the Namurian of Hagen-Vorhalle (Germany), J. Zool. Syst. Evol. Res., 39, 209-226, 2001.

Bell, W. A.: Carboniferous rocks and fossil floras of northern Nova Scotia, Geol. Surv. Can., Mem., 238, iv+277 pp., 2 tabs, https://doi.org/10.4095/119859, 1944.

Bell, W. A.: Flora of the Pennsylvanian Pictou Group of New Brunswick, Geol. Surv. Can., Bull., 87, ix+71 pp., 56 pls, index, https://doi.org/10.4095/100605, 1962.

Béthoux, O.: The Late Carboniferous Triplosoba pulchella is not a fly in the ointment but a stem-mayfly, Syst. Entomol., 40, 342356, https://doi.org/10.1111/syen.12103, 2015.

Béthoux, O., Llamosi, A., and Toussaint, S.: Reinvestigation of Protelytron permianum (Insecta; Early Permian; USA) as an example for applying reflectance transformation imaging to insect imprint fossils, Foss. Rec., 20, 1-7, https://doi.org/10.5194/fr-20-12016, 2016.

Béthoux, O., Norrad, E. N., Stimson, M., King, A., Allen, L. F., Deregnaucourt, I., Hinds, S. J., Lewis, J. H., and Schneider, J. W.: Data from: A unique, large-sized stemOdonata (Insecta) found in the early Pennsylvanian of New Brunswick (Canada), Dryad Digital Repository [data set], https://doi.org/10.5061/dryad.fttdz08s0, 2021.

Brauckmann, C.: Zwei neue Insekten (Odonata, Megasecoptera) aus dem Namurium von Hagen-Vorhalle (West-Deutschland), Dormunter Beitr. Landeskde, Naturwiss. Mitt., 22, 91-101, 1988.

Brauckmann, C. and Zessin, W.: Neue Meganeuridae aus dem Namurium von Hagen-Vorhalle (BDR) und die Phylogenie des Meganisoptera, Dtsch. Entomol. Z. (N.F.), 36, 177-215, 1989.

Brauckmann, C., Koch, L., and Kemper, M.: Spinnentiere (Arachnida) und Insekten aus den Vorhalle-Schichten (Namurium B; Ober-Karbon) von Hagen-Vorhalle (West-Deutschland), Geol. Paläontol. Westfalen, 3, 1-132, 1985.

Calder, J. H., Gibling, M. R., Scott, A. C., Davies, S. J., and Hebert, B. L.: A fossil lycopsid forest succession in the classic Joggins section of Nova Scotia: Paleoecology of a disturbance-prone Pennsylvanian wetland, in: Wetlands through time, edited by: Greb, S. F. and DiMichele, W. A., Geol. Soc. Am. special papers, 399, 169-195, https://doi.org/10.1130/2006.2399(09), 2006.
Carpenter, F. M.: Superclass Hexapoda, in: Treatise on Invertebrate Paleontology, edited by: Kaesler, R. L., The Geological Society of America and the University of Kansas, Boulder, xxii+655 pp., 1992.

Copeland, M. J.: The arthropod fauna of the Upper Carboniferous rocks of the Maritime Provinces, Geol. Surv. Can., Mem., 286, 110 pp., https://doi.org/10.4095/101505, 1957.

Dawson, J. W.: Acadian geology: the geological structure, organic remains, and mineral resources of Nova Scotia, New Brunswick, and Prince Edward Island (3rd edition), Macmillan, London, UK, xxvi+790 pp., https://doi.org/10.5962/bhl.title.18064, 1878.

Dietrich, J., Lavoie, D., Hannigan, P., Pinet, N., Castonguay, S., Giles, P., and Hamblin, A.: Geological setting and resource potential of conventional petroleum plays in Paleozoic basins in eastern Canada, Bull. Can. Petrol. Geol., 59, 54-84, https://doi.org/10.2113/gscpgbull.59.1.54, 2011.

Dyer, W. S.: Minto Coal Basin New Brunswick, Geol. Surv. Can., Mem., 151, 1-42, 42 map sheets, https://doi.org/10.4095/100845, 1926.

Fabricius, J. C.: Entomologia systematica emendata et aucta. Secundum classes, ordines, genera, species adjectis synonimis, locis, observationibus, descriptionibus. Tome 2, Proft, C. G., Copenhagen, viii+519 pp., 1793.

Faulkner, S. J. M., Stimson, M. R., Calder, J. H., and Lucas, S. G.: The first unambiguous pterygote ichnofossil from the Joggins Fossil Cliffs, UNESCO World Heritage Site, Joggins, Nova Scotia, Canada (Abstract to 43rd Colloquium \& Annual General Meeting 2017 of the Atlantic Geoscience Society), Atlantic Geol., 53, 141, https://doi.org/10.4138/atlgeol.2017.006, 2017.

Garrison, R. W., von Ellenrieder, N., and Louton, J. A.: Damselfly genera of the New World, John Hopkins University Press, Baltimore, Maryland, USA, 490 pp., 2010.

Gibling, M. R., Culshaw, N., Pascucci, V., Waldron, J. W. F., and Rygel, M. C.: The Maritimes Basin of Atlantic Canada: Basin creation and destruction during the Paleozoic assembly of Pangea, in: The Sedimentary Basins of the United States and Canada (Second edition), edited by: Miall, A., Elsevier, Amsterdam, Netherlands, 267-314, https://doi.org/10.1016/B978-0444-63895-3.00006-1, 2019.

Hamilton J. B.: Geological Notes - Chipman-Harcourt Area, Geol. Surv. Can., New Brunswick Dept. Nat. Res. Energy, Preliminary Map 60-01, 8 pp., 1 sheet, 1960.

Hamilton J. B.: Geological Notes - Codys, Queens and Kings Counties, Geol. Surv. Can., New Brunswick Dept. Nat. Res. Energy, Preliminary Map 59-05, 21 pp., 1 sheet, 1962a.

Hamilton J. B.: Geological Notes - Salisbury "West", Queens, Kings and Westmorland Counties, Geol. Surv. Can., New Brunswick Dept. Nat. Res. Energy, Preliminary Map 60-05, 16 pp., 1 sheet, $1962 b$.

Hamilton J. B.: Geological Notes - Chipman "East", Queens County, Geol. Surv. Can., New Brunswick Dept. Nat. Res. Energy, Preliminary Map 60-06, 16 pp., 1 sheet, 1962c.

Haquebard, P. A.: The Carboniferous of Eastern Canada, Compte Rendu 7th International Congress of Carboniferous Stratigraphy and Geology, 1971, Krefeld, 1972.

Haquebard, P. A. and Barss, M. S.: Paleogeography and facies aspects of the Minto coal seam, New Brunswick, Canada, Compte Rendu 6th International Congress on Carboniferous Stratigraphy and Geology, 1967, Sheffield, 1970. 
Jacquelin, L., Desutter-Grandcolas, L., Chintauan-Marquier, I. C., Boistel, R., Zheng, D., Prokop, J., and Nel, A.: New insights on basivenal sclerites using 3D tools and homology of wing veins in Odonatoptera (Insecta), Sci. Rep., 8, 238, https://doi.org/10.1038/s41598-017-18615-0, 2018.

Lameere, A.: Sur la nervation alaire des insectes, Bull. Cl. Sci. Acad. Roy. Belg., 8, 138-149, 1922.

Lameere, A.: On the wing-venation of insects, Psyche, 30, 123-132, https://doi.org/10.1155/1923/16920, 1923.

Lavoie, D., Pinet, N., Dietrich, J., Hannigan, P., Castonguay, S., Hamblin, A. P., and Giles, P.: Petroleum Resource Assessment, Paleozoic successions of the St. Lawrence Platform and Appalachians of eastern Canada, Geol. Surv. Can., open file 6174, 1-273, https://doi.org/10.4095/248071, 2009.

Li, Y., Béthoux, O., Pang, H., and Ren, D.: Early Pennsylvanian Odonatoptera from the Xiaheyan locality (Ningxia, China): new material, taxa, and perspectives, Foss. Rec., 16, 117-139, https://doi.org/10.1002/mmng.201300006, 2013.

Matthew, G. F.: Remarkable forms of the Little River group, Proc. Trans. Roy. Soc. Can., 3, 115-133, 1909.

McAlpine, D. F.: In Memory: Paul-Michael Brunelle (7 November 1952-18 January 2020), Bull. Entomol. Soc. Can., 52, 118-119, 2020.

Muller, J. E.: Geology and coal deposits of Minto and Chipman map-areas, New Brunswick, Geol. Surv. Can., Mem., 260, i-v, 1-40, 43 map sheets, https://doi.org/10.4095/101597, 1951.

Nel, A., Béthoux, O., Bechly, G., Martínez-Delclòs, X., and Papier, F.: The Permo-Triassic Odonatoptera of the "protodonate" grade (Insecta: Odonatoptera), Ann. Soc. Entomol. Fr. (N.S.), 37, 501525, 2001

Nel, A., Garrouste, R., and Roques, P.: A new griffenfly genus from the Late Carboniferous of northern France (Odonatoptera: Meganeuridae), Insect Syst. Evol., 39, 231-239, 2008.

Nel, A., Fleck, G., Garrouste, R., Gand, G., Lapeyrie, J., Bybee, S. M., and Prokop, J.: Revision of Permo-Carboniferous griffenflies (Insecta: Odonatoptera: Meganisoptera) based upon new species and redescription of selected poorly known taxa from Eurasia, Palaeontograph. Abt. A, 289, 89-121, 2009.

Nel, A., Garrouste, R., and Schubnel, T.: Response to Trueman and Rowe (2019) "The wing venation of Odonata. International Journal of Odonatology", Int. J. Odonatol., 22, 115-119, https://doi.org/10.1080/13887890.2019.1602085, 2019.

Petrulevičius, J. F. and Gutiérrez, P. R.: New basal Odonatoptera (Insecta) from the lower Carboniferous (Serpukhovian) of Argentina, Arq. Entomol., 16, 341-358, 2016.

Prokop, J., Pecharová, M., Nel, A., Grey, M., and Hörnschemeyer, T.: A remarkable insect from the Pennsylvanian of the Joggins Formation in Nova Scotia, Canada: insights into unusual venation of Brodiidae and nymphs of Megasecoptera, J. Syst. Paleontol., 15, 1051-1065, https://doi.org/10.1080/14772019.2017.1283364, 2017.

Pruvost, P.: Un ancêtre des libellules dans le terrain houiller de Tchécoslovaquie, Ann. Soc. Géol. Nord, 58, 149-155 + pl. 145, 1933.

Riek, E. F.: A new collection of insects from the Upper Triassic of South Africa, Ann. Natal Mus., 22, 791-820, 1976.

Riek, E. F. and Kukalová-Peck, J.: A new interpretation of dragonfly wing venation based upon Early Upper Carboniferous fossils from Argentina (Insecta, Odonatoidea) and basic charac- ter states in pterygota wings, Can. J. Zool., 62, 1150-1166, https://doi.org/10.1139/z84-166, 1984.

Rohdendorf, B. B.: Podklass Pterygota, krilatie nacekomie [Subclass Perygota, winged insects], in: Osnovy Paleontologii [Fundamentals of Palaeontology], edited by: Rohdendorf, B. B., Izdatel'stvo Akademii Nauk SSSR, Moscow, 49-359, 1962.

St. Peter, C. J. and Johnson, S.: Stratigraphy and structural history of the late Paleozoic Maritimes Basin in southeastern New Brunswick, Canada, New Brunswick Dep. Nat. Res., Mem., 3, i-xii, 1-348, 2009.

Su, Y., Zhang, Z., and Hong, Y.: Two new ancient dragonflies (Insecta: Odonatoptera) from the Namurian of Ningxia, China, Insect Syst. Evol., 43, 1-10, https://doi.org/10.1163/187631212X624205, 2012.

Tillyard, R. J.: The British Liassic dragonflies (Odonata), Fossil insects series, edited by: Trustees of the British Museum British Museum (Natural History), London, 40 pp., pls I-V, 1925a.

Tillyard, R. J.: Kansas Permian insects. Part 5. The order Protodonata and Odonata, Am. J. Sc., 10, 41-73, https://doi.org/10.2475/ajs.s5-10.55.41, 1925 b.

Tillyard, R. J. and Fraser, N. C.: A reclassification of the Order Odonata based on some new interpretations of the venation of the dragonfly wing, Austr. Zool., 9, 124-169, 1938.

Trueman, J. W. H. and Rowe, R. J.: The wing venation of Odonata, Int. J. Odonatol., 22, 73-88, https://doi.org/10.1080/13887890.2019.1570876, 2019a.

Trueman, J. W. H. and Rowe, R. J.: Reply to Nel, Garrouste, and Schubnel (2019) "The wing venation of Odonata. International Journal of Odonatology”, Int. J. Odonatol., 22, 167-172, https://doi.org/10.1080/13887890.2019.1654932, 2019b.

Van Allen, H. E. K., Calder, J. H., and Hunt, A. P.: The trackway record of a tetrapod community in a walchian conifer forest from the Permo-Carboniferous of Nova Scotia, in: The Nonmarine Permian, edited by: Lucas, S. G. and Zeigler, K. E., New Mex. Mus. Nat. Hist. Sci. Bull., 30, 322-332, 2005.

van de Poll, H. W., Gibling, M. R., and Hyde, R. S.: Upper Paleozoic rocks. in: Geology of the Appalachian-Caledonian Orogen in Canada and Greenland, edited by: Williams, H., Geological Society of America, Ottawa, Canada, Geology of Canada Series 6, 449-566, https://doi.org/10.1130/DNAG-GNA-F1.447, 1995.

Williams, E. P.: Geology and petroleum possibilities in and around Gulf of St. Lawrence, Am. Assoc. Petrol. Geol. Bull., 58, 11371155, 1974.

Zessin, W.: Zur Taxonomie der jungpaläozoischen Familie Meganeuridae (Odonata) unter Einbezihung eines Neufundes aus dem Stephan C der Halleschen Mulde (DDR), Freib. Forsch. C, 384, 58-76, 1983

Zessin, W.: Zwei neue Insektenreste (Megasecoptera, Odonatoptera) aus dem Westfalium D (Oberkarbon) des Piesberges bei Osnabrück, Deutschland, Virgo, Mitteilungsblatt Entomol. Vereins Mecklenburg, 9, 37-45, 2006.

Zessin, W. and Brauckmann, B.: Aulertupus tembrocki n. gen. et sp. (Odonatoptera: Meganisoptera: Aulertupidae n. fam.) aus dem Ober-Karbon von Mazon Creek, Illinois (USA), Virgo, Mitteilungsblatt Entomol. Vereins Mecklenburg, 2, 36-43, 2010. 